\title{
Financial Access to Dental Care Through Health Insurance in Senegal
}

\author{
Diop Mbathio*, Kanouté Aida, Diouf Massamba, Ndiaye Amadou Diaw, \\ Lo Cheikh Mouhamadou Mbacké, Faye Daouda, Cissé Daouda \\ Department of Public Health Faculty of Medicine, University Cheikh Anta Diop of Dakar, Dakar, Senegal
}

\section{Email address:}

diopmbathio@yahoo.fr (D. Mbathio), aida_kanoute@yahoo.fr(K. Aida),dioufmass78@yahoo.fr (D. Massamba), adnndiaye@gmail.com (N. A. Diaw), cheikhlo54@yahoo.fr (L. C. M. Mbacké), daouda_faye2004@yahoo.fr (F. Daouda), daoudacisse@hotmail.com (C. Daouda)

${ }^{*}$ Corresponding author

\section{To cite this article:}

Diop Mbathio, Kanouté Aida, Diouf Massamba, Ndiaye Amadou Diaw, Lo Cheikh Mouhamadou Mbacké, Faye Daouda, Cissé Daouda. Financial Access to Dental Care Through Health Insurance in Senegal. Science Journal of Public Health. Vol. 5, No. 5, 2017, pp. $359-364$. doi: $10.11648 /$ j.sjph.20170505.11

Received: June 14, 2017; Accepted: June 28, 2017; Published: July 31, 2017

\begin{abstract}
Costs of oral disease care are among the most expensive health care cost. In Senegal, more than $20 \%$ of most health insurance companies' healthcare expenditure goes to dental care. A survey, which focused on the financial access to dental care through health insurance in Senegal, was carried out nationwide. The results show that $48.7 \%$ of surveyed heads of household have less than 50,000 FCFA monthly incomes, $41 \%$ of them have no knowledge of health insurance and only $14.3 \%$ are insured by mutual. While more than half of those mutual cover conservative care $(51.2 \%)$ and extractions $(53.5 \%)$, they do not for prostheses. Because health insurance partially covers dental care, whereas oral health care are very expensive, insurers and dental surgeons must join forces to contain the expenditure through awareness of community solidarity.
\end{abstract}

Keywords: Oral Care, Health Insurance, Senegal, Africa

\section{Introduction}

Access to health care, in general, and oral care in particular in most African countries is biased. Yet, oral diseaseis a major public health issue because of their high occurrence and huge impact on overall health and quality of life. They are considered the fourth most costly disease to treat worldwide [1]. In Africa, significant inequalities in oral health exist within, as well as between countries. In Senegal, the study carried out by the National Agency of Statistics and Demography [2] highlights the phenomena of impoverishment and the disastrous expenditure due to direct health care payments [3]. To qualify for direct payment, $32.88 \%$ of Senegalese households are to be considered poor. The impoverishment due to direct payments was at $0.96 \%$ in 2005 and $1.78 \%$ in 2011 [3]. Households bearing most of their health care expenditure at their own risk contributes to their increased poverty or a sudden extreme impoverishment [4].
Because of that, the Lancet September 2012 editorial confirms that "direct payments must be abandoned" [5]. Likewise, Ridde's results show that $59 \%$ of public health actors favor the abolition of direct payments or free healthcare [6].

Implementing health insurance in the healthcare system could improve the resort to oral health care by picking up the populations' health bill through voluntary and risks sharing, thus making easy access to health care.

For that reason, Senegal commits itself to a universal health coverage policy through the expansion of health insurance mutual. Can these mutual gradually contribute to the access to health care? The aim of this work is to study how health insurance can financially facilitate the access to oral health care in Senegal.

\section{Materials and Methods}

\subsection{Type of Study}

A cross-sectional and descriptive epidemiological survey 
was carried out.

\subsection{Targeted Population}

Any Senegalese residing in selected localities and who agreed to take part in the study was targeted.

\subsection{Selection Criteria}

The sample selection criteria are to:

a) be at least 18 years old at the time of the survey;

b) be responsible for the family's medical care;

c) live in chosen regions.

\subsection{Sampling}

The adopted sampling procedure is that of the WHO, described in its basic methods. Indeed, WHO's recommendations suggest the choice of 12 sites nationwide; 4 from the capital, 4 from two major regions and 4 regions from rural areas [7]. In other words, it consisted of surveying 100 households in the capital (Dakar), 100 in two economically important regions (Thiès and Diourbel) with respectively 50 households each, and 100 in 4 other regions drawn by lots. The study focused on health insurance. Therefore, we based the choice of the 4 sites on the Decentralization and Extension of Coverage of Health Insurance's project (DECHI) [8]. Thus, Saint-Louis, Louga, Kaolack and Kaffrine were selected. For each region, a department (except for Dakar where 2 departments were drawn) with districts was randomly drawn, then those districts with boroughs was drawn randomly (Table 1).

Table 1. Recap of selected districts.

\begin{tabular}{llll}
\hline Régions & Départements & Districts & Boroughs \\
\hline Dakar & Dakar & Dakar Plateau & Gorée, \\
& & & Gueule- Tapée \\
& Rufisque & Rufisque & Missirah, \\
Diourbel & Mbacké & Ndame & Touba Mosquée \\
Thiès & Thiès & KeurMoussa & Fandène \\
Louga & Kébémer & Ndande & Keur Moussa \\
Saint-Louis & Saint-Louis & Rao & Dioukoul- Diawrigne \\
Kaffrine & Mbirkilane & Mabo & Fass Ngom \\
Kaolack & Nioro & Wack Ngouna & Mabo \\
\hline
\end{tabular}

In each borough, through a bottle drawing on the public square, from house to house, the person in charge of the family's medical carewas interviewed. In the absence of the head of household, the spouse is interviewed. In the case of districts with several neighborhoods (Gueule Tapée - Fass Colobane), one was chosen by drawing lots.

\subsection{Tools (Variables and Indicators)}

The information gathered to study the financial access refers to the incomes of heads of household, the satisfaction of insured members, the coverage terms, the package offered, the CMUC location.

\subsection{Data Collection}

Two students in dental surgery and a statistician were used to conduct the survey. After a two days' training, to assess the questionnaire's feasibility, a preliminary test on 10 households in the region of Dakar was performed. At the end, the questions were needed to be altered, such as what to do in the case of the head of the household's absence. After the survey, the interviewed family got educated in oral hygiene.

\subsection{Data Analysis}

At the end of the survey, CS Pro software version 6.3 was used to process the data collected. The R software was used for graphical representation and the SPSS software to format tables and draw charts.

\section{Results - Households' Socio-demographic Characteristics}

In all, 300 heads of household had participated in the study. Heads of households were on average 45 years old with a gap of 15 years around, $58.30 \%$ of surveyed households had more than six (6) members. Almost half of heads of household $(48.7 \%)$ have less than 50,000 FCFA monthly incomes and only $5.7 \%$ of heads of household earn 300,000 FCFA and more ( 1 US dollar $=610$ FCFA) (Table 2).

Table 2. Heads of household income range.

\begin{tabular}{lllll}
\hline $\begin{array}{l}\text { Terms (Thousand } \\
\text { F CFA) }\end{array}$ & Effective & Percentage & \multicolumn{2}{c}{$\begin{array}{l}\text { Confidence } \\
\text { intervals }\end{array}$} \\
\hline $0-50$ & 146 & 48,7 & 43,01 & 54,32 \\
$50-100$ & 26 & 8,7 & 5,48 & 11,85 \\
$100-150$ & 10 & 3,3 & 1,30 & 5,36 \\
$150-200$ & 7 & 2,3 & 0,63 & 4,04 \\
$200-300$ & 9 & 3,0 & 1,07 & 4,93 \\
300 et plus & 17 & 5,7 & 3,05 & 8,28 \\
PR & 85 & 28,3 & 23,23 & 33,43 \\
\hline
\end{tabular}

The study showed that only $14.3 \%$ of surveyed households are members of a mutual, with only $22.7 \%$ covered by health insurance (Fig. 1), (Table 3). 


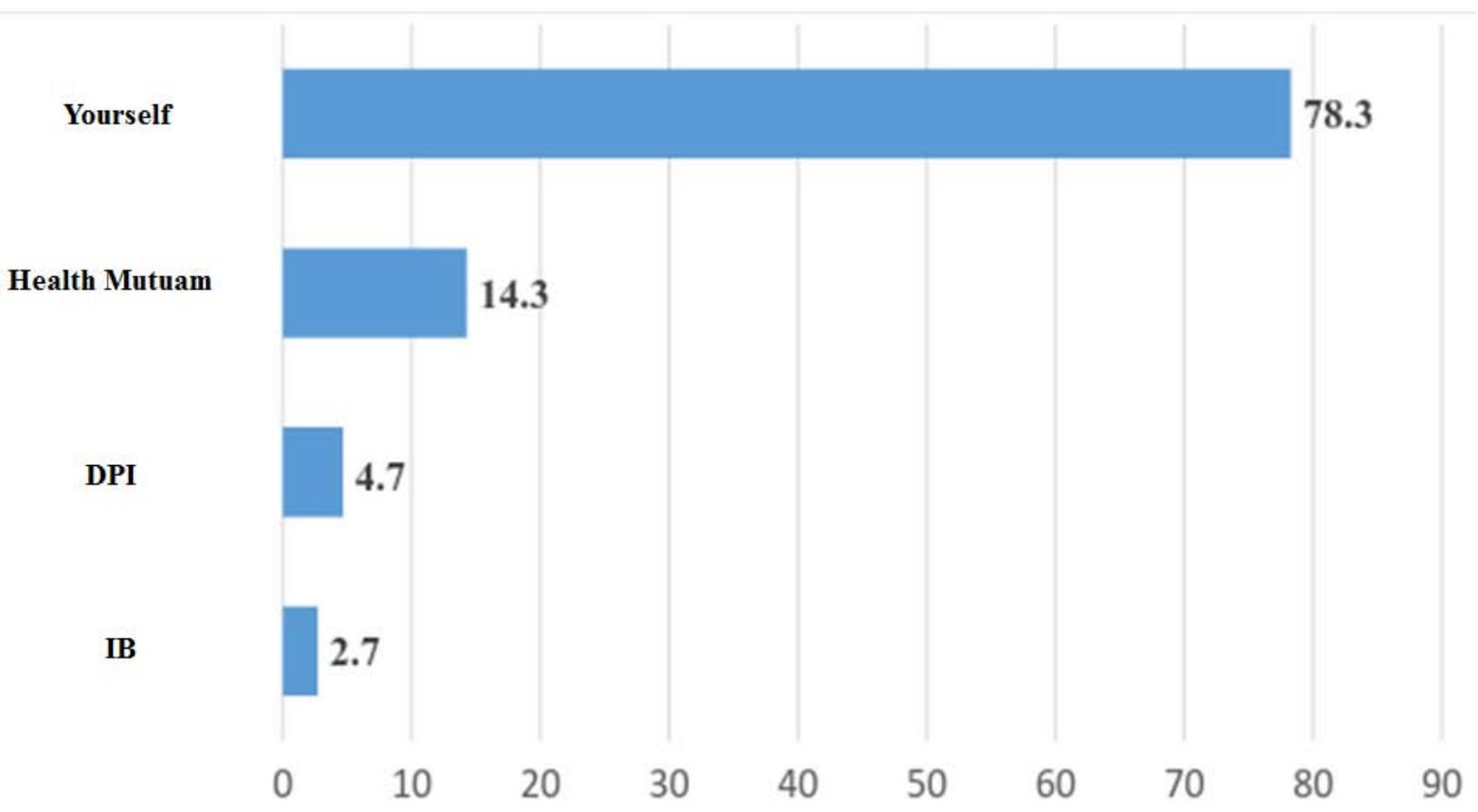

Distribution of the different types of coverage

Figure 1. Distribution of different types of coverage.

Table 3. Dental care coverage by health insurance.

\begin{tabular}{|c|c|c|c|c|c|}
\hline \multirow[t]{2}{*}{ Variables } & \multirow{2}{*}{$\begin{array}{l}\text { Terms } \\
\text { Do not know }\end{array}$} & \multirow{2}{*}{$\begin{array}{l}\text { Effective } \\
123\end{array}$} & \multirow{2}{*}{$\begin{array}{l}\text { Percentage } \\
41,00\end{array}$} & \multicolumn{2}{|c|}{ Confidence intervals } \\
\hline & & & & 35,43 & 46,57 \\
\hline \multirow{3}{*}{ Insurance services appreciation } & Satisfactory & 174 & 58,00 & 52,41 & 63,59 \\
\hline & Not much & 2 & 0,70 & 0,00 & 1,64 \\
\hline & Other & 1 & 0,30 & 0,00 & 0,92 \\
\hline \multirow{2}{*}{ Members' opinion about conservatives care } & No & 21 & 48,80 & 33,86 & 63,74 \\
\hline & Yes & 22 & 51,20 & 36,26 & 66,14 \\
\hline \multirow{2}{*}{ Members' opinion about extractions care } & No & 20 & 46,50 & 31,59 & 61,41 \\
\hline & Yes & 23 & 53,50 & 38,59 & 68,41 \\
\hline \multirow{2}{*}{ Members' opinion on dental coverage } & No & 7 & 16,30 & 5,26 & 27,34 \\
\hline & Yes & 36 & 83,70 & 72,66 & 94,74 \\
\hline \multirow{3}{*}{ Members' opinion on fees increase } & No & 25 & 58,10 & 43,35 & 72,85 \\
\hline & Yes & 18 & 41,90 & 27,15 & 56,65 \\
\hline & Yes & 297 & 99,00 & 97,87 & 100,13 \\
\hline \multirow[t]{2}{*}{ Heads of households' opinion on oral health care implementation } & No & 1 & 0,30 & 0,00 & 0,92 \\
\hline & Do not know & 2 & 0,70 & 0,00 & 1,64 \\
\hline \multirow{3}{*}{ Heads of household advised by dentist to join } & No & 299 & 99,70 & 99,08 & 100,32 \\
\hline & Yes & 1 & 0,30 & 0,00 & 0,92 \\
\hline & Yes & 285 & 95,00 & 92,53 & 97,47 \\
\hline \multirow[t]{2}{*}{ Willingness of heads of household to contribute to mutual } & No & 13 & 4,30 & 2,00 & 6,60 \\
\hline & Do not know & 2 & 0,70 & 0,00 & 1,64 \\
\hline \multirow{3}{*}{ Critic of insured on CMU } & Do not know & 20 & 46,50 & 31,59 & 61,41 \\
\hline & Good & 23 & 53,50 & 38,59 & 68,41 \\
\hline & Decrease contributions & 11 & 25,58 & 12,54 & 38,62 \\
\hline \multirow{3}{*}{ Insured expectations from $\mathrm{CMU}$} & Increase coverage & 7 & 16,28 & 5,24 & 27,31 \\
\hline & Other & 4 & 9,30 & 0,62 & 17,98 \\
\hline & None & 21 & 48,84 & 33,90 & 63,78 \\
\hline
\end{tabular}

HMs generally cover two types of benefits: preservatives care and dental extractions. Thus, they covered $51.2 \%$ of their members for conservative care and $53.5 \%$ for dental extractions. None of the mutual cover prostheses which most insured members wished for even though most of them
(58.1\%) are unwilling to increase their contributions foran extended coverage to overall oral health care. Most health insurance beneficiaries (53.5\%) value the Universal Health Coverage (UHC), even if $46.5 \%$ of them lack knowledge of it (Fig. 2). 


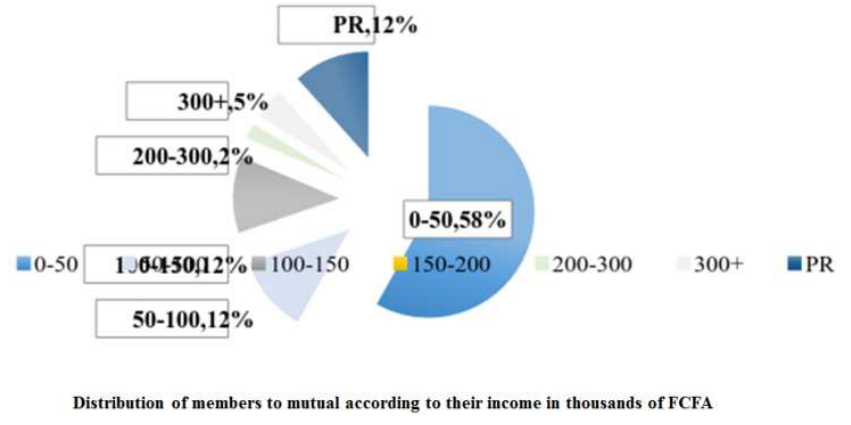

Figure 2. Distribution of members to mutual according to their incomse in thousands of FCFA.

Thus, heads of households with incomes below 50,000 FCFA are main members of the mutual. In fact, $58.14 \%$ of this group have less than 50,000 monthly incomes, with only $4.65 \%$ of them earning more than 300,000 FCFA per month.

\section{Discussion}

\subsection{Study's Boundaries}

The choice of certain regions was limited for the DECHI's project sites were used. There were some difficulties during the survey like the remoteness of certain localities, obtaining the neighborhood delegates' positive opinion, spotting a public square and the issue of heads of household withholding their incomes information.

\subsection{Socio-professional Characteristics}

In the sample, heads of household are, on average, 45 years old with a gap of 15 years around this average. This partition corroborates the findings of a 2014 survey where the proportion of heads of household was in the age bracket of 35-59 years old [9]. From a professional point of view, the structuration of the population shows that nearly third of heads of household are housewives. Also, merchants (16.7\%) and farmers $(15.7 \%)$ are significantly represented. Only $4 \%$ of heads of household are civil servants with a slight proportion of working class $(0.7 \%)$. These results could be explained by the fact that the majority of heads of household are women who devote most of their time to domestic activities, maternity and childcare [10]. These data are similar to those obtained from Burkina Faso [10], where the average monthly incomes per head is 7,945 FCFA along with significant disparities according to the head of household's socioeconomic profile.

The importance of the other method (23.7\%), which shows that many occupations (liberal sector, unpaid employee and unemployed) were not taken into account in the study should be stressed out. Moreover, the results show that some professional occupations are more practiced by men than women and vice versa. This phenomenon is found in Togo where more than half of people without paid employment $(58.6 \%)$ were stay at home women or men, followed by people in subsistence farming (23\%). Civil servants accounted for only $2.5 \%$ of the population [11].

The analysis of socio-demographic characteristics also concerns the size of households which is important insofar as it gives an overview of the social burden of heads of household. Thus, it was found that the majority of surveyed households (58.30\%) have more than six (6) members. These results are similar to those obtained by the National Agency for Statistics and Demography of Senegal [9], where a household is made up of an average of 8 people.

\subsection{Health Insurance}

Regarding health insurance, most surveyed households lack knowledge of it $(41.0 \%)$, compared to $58.0 \%$ who are satisfied with services received. Results of a Waelken' 2007 study show a low membership in West Africa [12], where heads of households even though they are willing to join a mutual, have never been advised to do so by a dentist. Many health insurance actors have reported the partial coverage in practice. In France in 2008, Vincelet C. found that the reimbursement of conservative and surgical care for registered practitioners was guaranteed [13]. Likewise, Inoua A. in Gabon in 2013 reveals the lack of coverage for esthetic treatments [14].

As a result, most heads of households (99\%) believe that Health Mutual should officially be part in the dental coverage decision. Most members wish to contribute between 3,000 and 4,000 FCFA per person, per year, which is within the range of membership fees of the mutual (3,500 FCFA) under the CMU, unlike Musango L's 2010 study, in Gabon, which shows that health insurance contributions vary according to categories [15].

At a regional level, Dakar and Diourbel have the most heads of households who are willing to contribute the most for health insurance, while Saint-Louis and Louga heads of household are less likely to pay for insurance. These disparities can be explained by the fact that the majority of heads of household living in Dakar and Diourbel have over 300,000 FCFA monthly incomes. A similar study in Burkina Faso shows that workers in the informal sector cannot afford these contribution fees [16].

\subsection{Use of Health Insurance}

Overall, the membership to mutual is limited $(14.3 \%$ of households); MPI and IB cover $7.4 \%$ of households, whereas, in Rwanda in 2009, the proportion of the population covered by health insurance was at $75.6 \%$ [17]. At the regional level, significant disparities with regions such as Thiès shows a widespread use of health insurance with $46.0 \%$ insured households, unlike Kaolack, Louga and Saint -Louis where none of surveyed households has health insurance. These results are due to the fact that Thiès is a pioneer in the field of mutual in Senegal but also in West Africa and has a rich experience on mutual. The study carried out by Lo et al. highlights the high number of members in this region. [18].

In addition, annual contributions to these mutual are higher than what heads of household are willing to pay for health insurance. Furthermore, annual contributions by region reveal more disparities which, however, are statistically insignificant (at the 95\% threshold), meaning that contributions are 
statistically the same in all regions. Moreover, although the average of annual contributions is expensive, the most enrolled for benefits are heads of households with incomes below 50,000 FCFA. Other studies show that the low level of incomes of households is a major hurdle to enrollment for health insurance scheme $[4,14,19]$. Mutual members, as well as non-mutual members, explain the low membership for lack of financial resources $[4,14]$. This contrast may be explained by the fact that the majority of members are farmers (Thiès) who live in a community enabling them to share timely information.

Moreover, mutual of health insurance generally cover two types of services: conservative care and dental extractions. Faye's work in Senegal in 2012 reveals that dental care costs are expensive for health insurance institutions because they spend over $20 \%$ of their overall health expenditure for it [20].

None of the mutual supports dental prostheses; when most of their members $(85.7 \%)$ want to be covered for. These data validate those of Lo [21]. Most members believe that services offered by their mutual meet their oral health needs. The Kerak E. study, in Morocco, in 2007, shows that $71.53 \%$ of members of mutual are dissatisfied with services offered [22]. Yet, more than half of insured (58.1\%) are not ready to increase their contributions. These results are contrary to those obtained by Lo [21] where $70 \%$ of insured were willing to increase their contributions. It should also be pointed out that a large proportion of insured persons (46.5\%) lack knowledge of the specific oral health services covered by their health insurance. This misunderstanding of HMs was due to the lack of awareness among members in addition to the non-functional MHOs in certain areas.

Moreover, it was reported a lack of total support from HMs.

Most heads of household (58\%) liked the CMU very much; Criel et al. in 2006, showed that health insurance improves access to quality care [23].

In order to perpetuate the Universal Health Coverage (UHC), populations must enroll as much as possible to health insurance mutual. Thus, in our study, the majority of insured appreciate it well, even if $46.5 \%$ of them lack knowledge of it. Members suggested the reduction of contributions, especially for heads of large households. A recent multi-level study in 41 developing countries showed that up to $6.8 \%$ of households have incurred dental care expenses in the last four weeks that were equal to or greater than $40 \%$ of what they can afford to pay; the so-called catastrophic dental health expenses [24].

Likewise, heads of household swish an anti-lobbying of the CMU and the strengthening of the quality of services in hospitals. Moreover, Joseph Kutzin, in 2016, reports that universal health coverage is a means to strengthen the health system [25].

\section{Conclusion}

In Senegal, indigent needs health insurance to access to care. Oral pathology is one of the major public health concerns, in Africa and in Senegal in particular, and its coverage through health insurance still does not meet the treatment plan' requirements. Financially speaking, dental care is a heavy burden on the health insurance budget, which covers it partially, favoring healing on the esthetics. It is therefore important to educate dental surgeons, health insurance managers and users about the need for close collaboration in order to ensure good care for oral health.

\section{Abbreviations}

\author{
WHO: World Health Organization \\ USD: United States Dollars \\ HM: Health Mutual \\ DPI: Disease Prevention Institution \\ FCFA: Franc des Colonies Françaises d'Afrique
}

\section{References}

[1] World Dental Federation. Conduire le monde a une santé bucco-dentaire optimale, La Vision 2020 de la FDI. Une prospection surl'avenir de la santé bucco-dentaire 2011.

[2] ANSD. L'Enquête de Suivi de la Pauvreté au Sénégal 2005 2006, MEF/ANSD, Août 2007, 1-89.

[3] Sow, M., Diop, M., Mbengue, A., Aw, A., Sall, FL., Cissé, A., Rapport d'analyse sur les dépenses catastrophiques de santé et leur impact sur l'appauvrissement et l'utilisation des services au Sénégal 2005 et 2011. African Health Monitor 2013.

[4] Dussault, G., Fournier, P., Letourmy, A. L'Assurance maladie en Afrique francophone: Améliorer l'accès aux soins et lutter contre la pauvreté, la banque mondiale Washington, DC. 2006.

[5] Editorial: The struggle for universal health coverage. Lancet 2012, 380: 859 .

[6] Robert E, Ridde V. les paiements directs dans les pays à faible et moyen revenu ne font plus l'unanimité au sein de la communauté internationale. Cahiers du CIRDIS Collection recherche. 2012, N3.

[7] World Health Organization. Oral health surveys: basic methods, WHO 1997 4th. ed.

[8] Ministère de la Sante et de l'action Sociale. Plan stratégique de développement de la Couverture Maladie Universelle au Sénégal. 2013-2017. 2013.

[9] Ministère de l'Economie, des Finances et du Plan du Sénégal. Agence Nationale de la Statistique et de la Démographie, Recensement Général de la Population et de l'Habitat, de l'Agriculture et de l'Elevage (RGPHAE 2013). 2014.

[10] Programme Alimentaire Mondiale. Evaluation approfondie de la sécurité alimentaire des ménages dans 170 communes déclarées à risque d'insécurité alimentaire au Burkina Faso. 2012.

[11] Agoudavi K. Ministère de la santé Togo. Rapport final de l'enquête STEPS Togo 2010. 2012.

[12] Carrin G, Waelkens MP, et Criel B. Community-based health insurance in developing countries: a study of its contribution to the performance of health financing systems. Trop Med Int. Health. 2005; 10(8): 799-811. 
[13] Vincelet C, Azogui-Lévy S, Grémy I. Etat bucco-dentaire et recours aux soins préventifs et curatifs de la population francilienne adulte. Observatoire régional de santé d'Ile-de-France, Ile-de-France. 2008: 112 p.

[14] Inoua A, Musango L. La Caisse nationale d'assurance maladie et de garantie sociale du Gabon: un chemin vers la couverture universelle. African Health Monitor. 2013; 17(2): 15-19.

[15] Musango L, Inoua A. Assurance maladie au Gabon: Un atout pour le bien être de la population. 2010; 11(3): 45-47

[16] Haddad S, Nougtara A, Ridde V. Les inégalités d'accès aux services de santé et leurs déterminants au Burkina Faso. Santé, sociétéetsolidarité. 2004; 3(2): 199-210.

[17] Musango L, Doetinchem O et Carrin G. De la mutualisation au risque maladie à l'assurance maladie universelle: Experience du RWANDA. 2009; 27(2): 112-118.

[18] LoCMM, Cisse D, Faye D et al. Accessibilité financière des soins bucco-dentaires aux populations du département de Thiès. Rev. Col. Odonto-Stomatol. Afr. Chir. Maxillo-Fac. 2009; 16: $41-45$

[19] Basaza R, Criel B, Van Der Stuyft P. Community health insurance in Uganda: Why does enrolment remain low? A view from beneath, Health Policy. 2008; 87(2): 172-184.
[20] Faye D, Cissé D, Diouf M, Kanouté A, Baldé YS. Part des dépenses des soins buccodentaires dans les dépenses de santé des institutions de protection sociale du Sénégal. Cahier de santé publique. 2012; 11(2): 40-46.

[21] Lo CMM, Cissé D, Diouf M et al. Prise en charge de la prothèse dentaire par les mutuelles de santé de la région de Dakar: revue col odonto-stomatolAfrchirMaxillo-fac. 2011; 18(14): 23-26.

[22] Kerak E, El Massaoui A, Imlahi A, Barrijal S. Étude de satisfaction des «clients» d'un organisme gestionnaire d'assurance maladie $\mathrm{Au}$ Maroc. Assurances et gestion des risques. 2007; 75(3): 391-408.

[23] Criel B, Blaise P, Ferette D. Mutuelles de santé en Afrique et qualité des soins dans les services: une interaction dynamique, in Dussault G., Fournier P., Letourmy A. (eds.) 2006; 12(2): 353-372.

[24] Masood M, Sheiham A, Bernabé E. A. PLoS One. 2015; 10(4): e0123075

[25] Kutzin J, Sparkes SP. System strengthening, universal coverage, health security and resilience. Bull World Health Organ.2 016. 1; 94(1): 2 . 